\title{
0990. Role of amplitude and rate of deformation in ventilator-induced lung injury
}

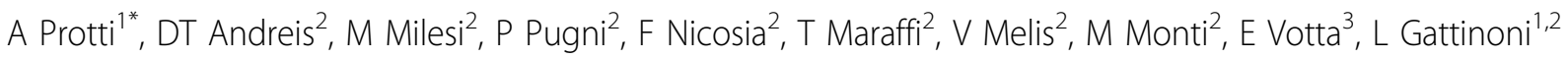 \\ From ESICM LIVES 2014 \\ Barcelona, Spain. 27 September - 1 October 2014
}

\section{Introduction}

Increasing both Tidal Volume $\left(\mathrm{V}_{\mathrm{T}}\right)$ (amplitude of lung deformation) and Inspiratory Flow (V') (rate of lung deformation) augments incidence of Ventilator-Induced Lung Injury (VILI) [1].

\section{Objectives}

To clarify whether increasing $V^{\prime}$ at constant $V_{T}$ augments incidence of VILI.

\section{Methods}

Twenty-eight healthy piglets were mechanically ventilated for up to 54 hours. Each animal was assigned to one of three groups of $\mathrm{V}_{\mathrm{T}}(300-400 \mathrm{ml} ; 500-600 \mathrm{ml} ; 750 \mathrm{ml})$ and one of two groups of V'. Lower and higher V' were obtained by setting inspiratory-to-expiratory time ratio as high as $1: 2$ or as low as 1:9. Respiratory rate was always 15 breaths per minute. Interplay between $\mathrm{V}_{\mathrm{T}}$ and $\mathrm{V}^{\prime}$ was assessed at the beginning of the study as airway pressurevolume loop area (or dynamic respiratory system hysteresis). VILI was defined as pulmonary oedema (lung weight gain $\geq 10 \%$ across the study period).

\section{Results}

Main findings are reported in Table 1.

\section{Conclusions}

Increasing $\mathrm{V}^{\prime}$ (rate of lung deformation) while maintaining $\mathrm{V}_{\mathrm{T}}$ (amplitude of lung deformation) constant augments incidence of VILI. Further studies are needed to clarify whether dynamic respiratory system hysteresis is an independent predictor of VILI.

\section{Grant acknowledgment}

This study was supported in part by an Italian grant provided by Fondazione Fiera di Milano for Translational and Competitive Research (2007, Luciano Gattinoni) and by GE Healthcare.

\section{Authors' details}

${ }^{1}$ Fondazione IRCCS Ca' Granda - Ospedale Maggiore Policlinico, Milan, Italy. ${ }^{2}$ Università degli Studi di Milano, Milan, Italy. ${ }^{3}$ Politecnico di Milano, Milan, Italy.

\section{Published: 26 September 2014}

\section{Reference}

1. Protti $A$, et al: Lung stress and strain during mechanical ventilation: any safe threshold? Am J Respir Crit Care Med 2011, 183:1354-1362.

Table 1 Inspiratory flow and incidence of VILI

\begin{tabular}{|c|c|c|c|c|c|c|}
\hline & \multicolumn{2}{|c|}{$\mathrm{V}_{\mathrm{T}} 300-400 \mathrm{ml}$} & \multicolumn{2}{|c|}{$\mathrm{V}_{\mathrm{T}} 500-600 \mathrm{ml}$} & \multicolumn{2}{|c|}{$\mathrm{V}_{\mathrm{T}} 750 \mathrm{ml}$} \\
\hline & Lower V' & Higher V' & Lower V' & Higher V' & Lower V' & Higher V' \\
\hline Tidal volume (ml) & $338 \pm 48$ & $335 \pm 42$ & $530 \pm 27$ & $520 \pm 27$ & $750 \pm 0$ & $750 \pm 0$ \\
\hline Inspiratory flow (ml/sec) & $272 \pm 36$ & $838 \pm 105^{*}$ & $398 \pm 21$ & $1278 \pm 38^{*}$ & $600 \pm 84$ & $1242 \pm 95^{*}$ \\
\hline Hysteresis $\left(\mathrm{ml}^{*} \mathrm{cmH}_{2} \mathrm{O}\right)$ & $6260 \pm 2236$ & $12938 \pm 3356^{*}$ & $11101 \pm 4508$ & $34126 \pm 4508^{*}$ & $18415 \pm 3520$ & $46915 \pm 7954^{*}$ \\
\hline Incidence of VILI & $0 / 4$ & $1 / 5$ & $0 / 5$ & $4 / 5^{*}$ & $2 / 5$ & $4 / 4$ \\
\hline
\end{tabular}

Data are presented as mean \pm standard deviation. ${ }^{*} \mathrm{p}<0.05$ vs. Lower $\mathrm{V}^{\prime}$ within the same $\mathrm{V}_{\mathrm{T}}$ group (Student's $t$, Mann-Whitney Rank Sum or Fisher's exact tests). Hysteresis was associated with incidence of VILI $(R=0.68, p<0.0001)$ (Spearman Rank Order Correlation).

\footnotetext{
${ }^{1}$ Fondazione IRCCS Ca' Granda - Ospedale Maggiore Policlinico, Milan, Italy
}

Full list of author information is available at the end of the article

(c) 2014 Protti et al; licensee Springer. This is an Open Access article distributed under the terms of the Creative Commons Attribution License (http://creativecommons.org/licenses/by/2.0), which permits unrestricted use, distribution, and reproduction in any medium, provided the original work is properly cited. 
doi:10.1186/2197-425X-2-S1-P75

Cite this article as: Protti et al:: 0990. Role of amplitude and rate of deformation in ventilator-induced lung injury. Intensive Care Medicine Experimental 2014 2(Suppl 1):P75.

\section{Submit your manuscript to a SpringerOpen ${ }^{\mathcal{O}}$ journal and benefit from:}

- Convenient online submission

- Rigorous peer review

- Immediate publication on acceptance

- Open access: articles freely available online

- High visibility within the field

- Retaining the copyright to your article

Submit your next manuscript at $\gg$ springeropen.com 